\title{
HUBUNGAN PEMBELAJARAN KESEHATAN REPRODUKSI REMAJA DENGAN PENGETAHUAN TENTANG NAPZA SISWA SMU DI SURAKARTA
}

\author{
Soetrisno ${ }^{1}$, Didon Muhammad Trimulya ${ }^{2}$, Slamet Riyanto ${ }^{3}$
}

\begin{abstract}
Background: Narcotics, psychotropic and other addictive substances misuse (drugs abuse) could effect various society segments, mostly young people age 15-24 years. The young generation is a strategic target for drug distribution including illegal trade in Surakarta. Necessary precautions should be taken as it could lead to addiction, could affect on survival, especially the young generation, including senior high school students. Policy to introduce adolescent reproductive health (ARH) education in particular with drugs abuse topic has been enacted in Surakarta since 2012, but had not covered the entire high school.

Objective: Observing the correlation between adolescent reproductive health education with knowledge of NAPZA on high school students in Surakarta.

Method: This study used an observational analytic with cross sectional design. A total of 120 students were taken by purposive random sampling. Total of 120 students were involved from second grade they consisted 60 students who had been given adolescent reproductive health education for one year (since first grade) and 60 students who had not. Students were given a questionnaire about NAPZA that has been tested for validity and reliability. Data analysis was then performed using chi-square.

Results and Discussion: There is a significant correlation between adolescent reproductive health education with knowledge about types, characteristic of high risk youth, sign of addiction, category of drug users, as well as the dangers of drug prevention among high school students in Surakarta $(p<0.05)$.

Conclusion: There is a significant correlation between adolescent reproductive health education with knowledge of NAPZA on high school students in Surakarta.
\end{abstract}

Keywords: Knowledge of NAPZA, Adolescent Reproductive Health Education, Youth of Surakarta.

\begin{abstract}
ABSTRAK
Latar Belakang: Penyalahgunaan Narkotika, Psikotropika, dan Zat adiktif lain (NAPZA) dapat dilakukan oleh berbagai lapisan masyarakat, terbanyak generasi muda 15-24 tahun. Generasi muda adalah sasaran strategis perdagangan gelap NAPZA termasuk di Surakarta. Diperlukan kewaspadaan terhadap bahaya serta pengaruh NAPZA yang dapat menimbulkan ketagihan, dengan dampak terhadap kelangsungan hidup dengan pembinaan, khususnya generasi muda termasuk siswa Sekolah Menengah Umum (SMU). Kebijakan pembelajaran kesehatan reproduksi remaja (KRR) khususnya topik NAPZA telah diberlakukan di Surakarta sejak ajaran baru 2012 sampai sekarang, namun belum mencakup keseluruhan SMU.

Tujuan: Mengamati hubungan pembelajaran KRR dengan pengetahuan NAPZA siswa SMU di Surakarta.

Metode: Penelitian observasional analitik rancangan cross sectional. 120 subyek penelitian (siswa) diambil secara purposive random sampling. Sebanyak 60 subyek penelitian diambil dari siswa SMU kelas 2 yang sudah mendapatkan pembelajaran KRR selama satu tahun (sejak kelas 1) dan sebanyak 60 subyek penelitian siswa SMU yang belum mendapatkan pembelajaran. Subyek penelitian, baik yang sudah dan belum mendapatkan
\end{abstract}

\footnotetext{
1,2 Bagian Obstetri dan Ginekologi, Fakultas Kedokteran Universitas Negeri Sebelas Maret Surakarta telp:0271-665145/0816672564

3 Dinas Kesehatan Kota Surakarta
} 
pembelajaran KRR diberikan kuesioner tentang NAPZA yang sudah diuji validitas dan reliabilitas. Kemudian dilakukan uji chi square.

Hasil dan Pembahasan: Terdapat hubungan bermakna pembelajaran KRR dengan pengetahuan tentang jenis, ciri remaja beresiko pengguna, tanda kecanduan, golongan gangguan pengguna, bahaya serta penanggulangan NAPZA siswa SMU di Surakarta ( $p<0.05)$.

Kesimpulan: Terdapat hubungan bermakna pembelajaran Kesehatan Reproduksi Remaja (KRR) dengan pengetahuan tentang NAPZA siswa SMU di Surakarta.

Kata Kunci: Pengetahuan NAPZA, KRR, siswa SMU

\section{PENDAHULUAN}

Narkotika, Psikotropika, dan Zat adiktif lain (NAPZA) adalah bahan/ zat yang dapat mempengaruhi kondisi kejiwaan/ psikologi seseorang (pikiran, perasaan dan perilaku) serta dapat menimbulkan ketergantungan fisik dan psikologi. ${ }^{1,2}$

Menurut laporan United Nations Office Drugs and Crime 2009 menyatakan 149 sampai 272 juta penduduk dunia usia 15-64 tahun menyalahgunakan obat setidaknya satu kali dalam 12 bulan terakhir. Dari semua jenis obat terlarang ganja merupakan zat yang paling banyak digunakan di seluruh dunia yaitu oleh 125 juta sampai dengan 203 juta penduduk dunia dengan prevalensi $2,8 \%-4,5 \%{ }^{3}$

Berdasarkan hasil survei Badan Narkotika Nasional (BNN) bekerjasama dengan Pusat Penelitian Kesehatan Universitas Indonesia (2011) memperkirakan prevalensi penyalahgunaan NAPZA pada tahun 2009 adalah 1,99\% dari penduduk Indonesia berumur 10-59 tahun. Pada tahun 2010, prevalensi penyalahgunaan NAPZA meningkat menjadi $2,21 \%$. Jika tidak dilakukan upaya penanggulangan diproyeksikan kenaikan penyalahgunaan NAPZA dengan prevalensi 2,8\% pada tahun 2015.

Survei Nasional BNN Tahun 2006 tentang Penyalahgunaan dan Peredaran Gelap NAPZA pada Kelompok Pelajar dan Mahasiswa di 33 Propinsi di Indonesia diperoleh hasil bahwa dari 100 pelajar dan mahasiswa rata-rata 8 orang pernah pakai dan 5 orang dalam setahun terakhir pakai NAPZA. Total penyalahgunaan NAPZA pada kelompok pelajar dan mahasiswa sebesar 1,1 juta jiwa dengan angka prevalensi 5,6\%.

Berdasarkan laporan Direktorat IV Narkoba dan KT BARESKRIM POLRI pada tahun 2007 diketahui kasus narkotika, psikotropika, dan bahan berbahaya sebanyak 22.630 kasus dengan proporsi kasus narkotika 50,28\%, proporsi kasus psikotropika $43,43 \%$ dan proporsi kasus bahan berbahaya $6,29 \%$. Sumatera Utara merupakan peringkat ketiga kasus terbanyak setelah Jawa Timur dan Metro Jaya (BNN, 2008). Berdasarkan data BNN jumlah pengguna NAPZA di Provinsi Sumatera Utara tahun 2010 sebanyak 2.065 kasus dan tahun 2011 sebanyak 2.068 kasus $^{4}$.

Yang termasuk dalam NAPZA adalah: Narkotika, Psikotropika dan Zat adiktif lainnya. ${ }^{1,2,3}$

\section{A. Narkotika}

Menurut UU RI No 22 / 1997, Narkotika adalah: zat atau obat yang berasal dari tanaman atau bukan tanaman baik sintetis maupun semisintetis yang dapat menyebabkan penurunan atau perubahan kesadaran, hilangnya rasa, mengurangi sampai menghilangkan rasa nyeri, dan dapat menimbulkan ketergantungan.

\section{Narkotika terdiri dari 3 golongan ${ }^{2,5,6}$ :}

1. Golongan I: Narkotika yang hanya dapat digunakan untuk tujuan pengembangan ilmu pengetahuan dan tidak digunakan dalam terapi, serta mempunyai potensi sangat tinggi mengakibatkan ketergantungan (contoh: Heroin, Kokain, Ganja). 
2. Golongan II: Narkotika yang berkhasiat pengobatan, digunakan sebagai pilihan terakhir dan dapat digunakan dalam terapi dan/atau untuk tujuan pengembangan ilmu pengetahuan serta mempunyai potensi tinggi mengakibatkan ketergantungan (contoh: Morfin, Petidin).

3. Golongan III: Narkotika yang berkhasiat pengobatan dan banyak digunakan dalam terapi dan / atau tujuan pengebangan ilmu pengetahuan serta mempunyai potensi ringan mengakibatkan ketergantungan (contoh: Codein).

\section{B. Psikotropika}

Menurut UU RI No 5 / 1997, Psikotropika adalah: zat atau obat, baik alamiah maupun sintetis bukan narkotika, yang berkhasiat psikoaktif melalui pengaruh selektif pada susunan saraf pusat yang menyebabkan perubahan khas pada aktifitas mental dan perilaku. Psikotropika terdiri dari 4 golongan ${ }^{5,7,8,9}$

1. Golongan I: Psikotropika yang hanya dapat digunakan untuk tujuan ilmu pengetahuan dan tidak digunakan dalam terapi, serta mempunyai potensi kuat mengakibatkan sindroma ketergantungan (contoh: Ekstasi).

2. Golongan II: Psikotropika yang berkhasiat pengobatan dan dapat digunakan dalan terapi dan / atau untuk tujuan ilmu pengetahuan serta mempunyai potensi kuat mengakibatkan sindroma ketergantungan (contoh: Amphetamine).

3. Golongan III: Psikotropika yang berkhasiat pengobatan dan banyak digunakan dalam terapi dan / atau untuk tujuan ilmu pengetahuan serta mempunyai potensi sedang mengakibatkan sindroma ketergantungan (contoh: Phenobarbital).

4. Golongan IV: Psikotropika yang berkhasiat pengobatan dan sangat luas digunakan dalam terapi dan / atau untuk tujuan ilmu pengetahu- an serta mempunyai potensi ringan mengakibatkan sindroma ketergantungan (contoh: Diazepam, Nitrazepam (BK, DUM)).

\section{Zat Adiktif Lainnya}

Yang termasukZat Adiktif lainnya adalah: bahan/ zat yang berpengaruh psikoaktif diluar Narkotika dan Psikotropika, meliputi

1. Minuman Alkohol: mengandung etanol etil alkohol, yang berpengaruh menekan susunan saraf pusat, dan sering menjadi bagian dari kehidupan manusia sehari-hari dalam kebudayaan tertentu. Jika digunakan bersamaan dengan Narkotika atau Psikotropika akan memperkuat pengaruh obat / zat itu dalam tubuh manusia. Ada 3 golongan minuman beralkohol ${ }^{6,7,9}$ :

a) Golongan A: kadar etanol 1-5\% (bir).

b) Golongan B: kadar etanol 5-20\% (berbagai minuman anggur)

c) Golongan C: kadar etanol $20-45 \%$ (Whisky, Vodca, Manson House, Johny Walker)

2. Inhalasi (gas yang dihirup) dan solven (zat pelarut) mudah menguap berupa senyawa organik, yang terdapat pada berbagai barang keperluan rumah tangga, kantor, dan sebagai pelumas mesin. Bahan yang sering disalahgunakan adalah: lem, tiner, penghapus cat kuku, bensin.

3. Tembakau: pemakaian tembakau yang mengandung nikotin sangat luas di masyarakat.

Dalam upaya penanggulangan NAPZA di masyarakat, pemakaian rokok dan alkohol terutama pada remaja, harus menjadi bagian dari upaya pencegahan, karena rokok dan alkohol sering menjadi pintu masuk penyalahgunaan NAPZA lain yang berbahaya.

Berdasarkan efeknya terhadap perilaku yang ditimbulkan dari NAPZA dapat digolongkan menjadi 3 golongan. ${ }^{5,6,8,9}$ 
1. Golongan Depresan (Downer), adalah jenis NAPZA yang berfungsi mengurangi aktifitas fungsional tubuh. Jenis ini membuat pemakainya menjadi tenang dan bahkan membuat tertidur bahkan tak sadarkan diri. Contohnya: Opioda (Morfin, Heroin, Codein), sedative (penenang), Hipnotik (obat tidur) dan Tranquilizer (anti cemas).

2. Golongan Stimulan (Upper), adalah jenis NAPZA yang merangsang fungsi tubuh dan meningkatkan kegairahan kerja. Jenis ini menbuat pemakainnya menjadi aktif, segar dan bersemangat. Contoh: Amphetamine (Shabu, Ekstasi), Kokain.

3. Golongan Halusinogen, adalah jenis NAPZA yang dapat menimbulkan efek halusinasi yang bersifat merubah perasaan, pikiran dan seringkali menciptakan daya pandang yang berbeda sehingga seluruh persaan dapat terganggu. Contoh: Kanabis (ganja).

Masalah penyalahgunaan NAPZA khususnya pada remaja adalah ancaman yang sangat mencemaskan bagi keluarga khususnya dan suatu bangsa pada umumnya. Pengaruh NAPZA sangatlah buruk, baik dari segi kesehatan pribadinya, maupun dampak sosial yang ditimbulkannya.

Dalam upaya penanggulangan NAPZA di masyarakat, Dinas Kesehatan Kota Surakarta bekerja sama dengan Sub Bagian Obstetri dan Ginekologi Sosial Fakultas Kedokteran Universitas Negeri Sebelas Maret Surakarta membuat kebijakan untuk me- laksanakan pembelajaran kesehatan reproduksi remaja di SMU. Hingga sekarang baru 25 SMU yang telah melaksanakan dan 35 SMU belum melaksanakan pembelajaran kesehatan reproduksi remaja. Studi ini dimaksudkan untuk mengetahui hubungan pembelajaran KRR dengan pengetahuan tentang NAPZA siswa SMU di Surakarta sebagai dasar untuk diberlakukan kebijakan pembelajaran KRR di seluruh SMU..$^{5,8,9}$

\section{METODE}

Penelitian ini menggunakan rancangan observasional analitik dengan metode cross sectional. Sebanyak 120 subyek penelitian (siswa SMU) diambil secara purposive random sampling. Dari 60 SMU di Surakarta, 35 SMU belum mendapat pembelajaran KRR sedangkan 25 SMU telah mendapat pembelajaran KRR. Secara random diambil 1 sekolah SMU yang belum dan 1 SMU yang sudah menjalankan pembelajaran KRR. Dari satu sekolah tersebut diambil sebagai sampai 2 kelas secara acak, dan akhirnya diambil 60 subyek secara acak. Seluruh subyek penelitian, baik yang sudah dan belum mendapatkan pembelajaran KRR diberikan kuesioner tentang NAPZA yang sebelumnya telah dilakukan uji validitas dan reliabilitas. Kemudian dilakukan analisis data dengan menggunakan chi square

\section{HASIL DAN PEMBAHASAN}

Sebanyak 25 SMU di wilayah Surakarta telah melakukan pembelajaran KRR, sedangkan 35 SMU lainnya belum melaksanakan pembelajaran tersebut. 
Tabel 1. Hubungan Pengetahuan tentang NAPZA dengan KRR

\begin{tabular}{|c|c|c|c|c|c|}
\hline Pengeth & $\begin{array}{c}\text { Sudah KRR } \\
n=60\end{array}$ & $\begin{array}{l}\text { Belum KRR } \\
\qquad n=60\end{array}$ & $\begin{array}{l}\text { Total } \\
N=120\end{array}$ & $\mathrm{RR}$ & $\mathbf{p}$ \\
\hline \multicolumn{6}{|l|}{ Jenis-jenis NAPZA } \\
\hline Tahu & $51(42.5 \%)$ & $5(4.1 \%)$ & $56(46.6 \%)$ & \multirow[t]{2}{*}{6.48} & \multirow[t]{2}{*}{$<0.05$} \\
\hline Tidak tahu & $9(7.5 \%)$ & $55(45.9 \%)$ & $64(53.4 \%)$ & & \\
\hline \multicolumn{6}{|l|}{ Ciri remaja berisiko } \\
\hline Tahu & $49(40.8 \%)$ & $7(5.8 \%)$ & $56(46.6 \%)$ & \multirow[t]{2}{*}{5.10} & \multirow[t]{2}{*}{$<0.05$} \\
\hline Tidak tahu & $11(9.2 \%)$ & $53(44.2 \%)$ & $64(53.4 \%)$ & & \\
\hline \multicolumn{6}{|l|}{ Tanda kecanduan } \\
\hline Tahu & $51(42.5 \%)$ & $4(3.7 \%)$ & $55(46.2 \%)$ & \multirow[t]{2}{*}{6.70} & \multirow[t]{2}{*}{$<0.05$} \\
\hline Tidak tahu & $9(7.5 \%)$ & $56(46.3 \%)$ & $65(53.8 \%)$ & & \\
\hline \multicolumn{6}{|l|}{$\begin{array}{l}\text { Penggolongan gangguan } \\
\text { NAPZA }\end{array}$} \\
\hline Tahu & $51(42.5 \%)$ & $6(5 \%)$ & $57(47.5 \%)$ & \multirow[t]{2}{*}{6.26} & \multirow[t]{2}{*}{$<0.05$} \\
\hline Tidak tahu & $9(7.5 \%)$ & $54(45 \%)$ & $63(52.5 \%)$ & & \\
\hline \multicolumn{6}{|l|}{ Bahaya NAPZA } \\
\hline Tahu & $51(42.5 \%)$ & $8(6.7 \%)$ & $59(49.2 \%)$ & \multirow[t]{2}{*}{5.86} & \multirow[t]{2}{*}{$<0.05$} \\
\hline Tidak tahu & $9(7.5 \%)$ & $52(43.3 \%)$ & $61(50.8 \%)$ & & \\
\hline \multicolumn{6}{|l|}{ Penanggulangan NAPZA } \\
\hline Tahu & $52(43.3 \%)$ & $7(5.8 \%)$ & $59(49.1 \%)$ & \multirow[t]{2}{*}{6.72} & \multirow[t]{2}{*}{$<0.05$} \\
\hline Tidak tahu & $8(6.7 \%)$ & $53(44.2 \%)$ & $64(50.9 \%)$ & & \\
\hline
\end{tabular}

Tabel 1 menunjukkan hubungan pengetahuan tentang NAPZA dengan pembelajaran KRR. Secara umum bahwa pengetahuan tentang NAPZA lebih tinggi secara bermakna (5-6 kali lebih tinggi) pada kelompok siswa yang telah mendapatkan pembelajaran KRR. Siswa yang telah mengikuti pembelajaran KRR lebih tinggi pengetahuannya dalam jenis NAPZA (RR 6,48), ciri-ciri remaja beresiko pengguna NAPZA (RR 5,10), tanda-tanda kecanduan NAPZA (RR 6,70), golongan gangguan pengguna NAPZA (RR 6,30), bahaya NAPZA (RR 5,90), dan cara penanggulangan NAPZA (RR 6,72).

Penelitian Putri, et al pada remaja SMK Negeri 2 Sragen menunjukkan bahwa sebagian besar responden memiliki upaya pencegahan yang baik terhadap penyalahgunaan narkoba yaitu sebanyak 93 orang $(64,6 \%) .{ }^{10}$ Hasil dari penelitian Widodo (2009) mendukung penelitian ini yang mengatakan bahwa remaja Desa Gonilan Sukoharjo cenderung berperilaku sehat dalam mencegah penyalahgunaan narkoba. Hasil penelitian yang dilakukan oleh Faturrachman, et al menyebutkan bahwa peran guru pembimbing sangat besar pengaruhnya terhadap upaya pencegahan dalam penanggulangan narkotika khususnya kepada para siswa SMU Negeri dan Swasta di Kota Palangkaraya dan umumnya kepada para remaja yang saat ini sedang berkembang, oleh karena itu disarankan perlu adanya pendekatan secara khusus kepada para siswa pecandu rokok, hendaknya diusahakan untuk dilaksanakan secara reguler adanya penyuluhan narkotika atau narkoba sehingga siswa dapat terhindar dari penyalahgunaan NAPZA. ${ }^{11}$

Beberapa penelitian membuktikan perlunya waktu yang relatif lama untuk keberhasilan suatu program pencegahan penyalahgunaan narkoba hingga ke tingkat perubahan perilaku. Untuk itu diperlukan adanya pelajaran mengenai penanggulangan bahaya narkoba pada remaja yang dapat 
dimasukkan ke dalam kurikulum SD, SMP, maupun SMU. ${ }^{12}$

Dari keterangan di atas, dapat dinyatakan bahwa pembelajaran tentang kesehatan reproduksi sangat penting dilaksanakan pada remaja, khususnya pada siswa SMU di Surakarta. Pembelajaran dalam hal ini dapat berupa ceramah dengan alat bantu maupun dengan metode lain. Kegiatan pembelajaran ini diharapkan dapat dimanfaatkan untuk menunjang kegiatan belajar-mengajar di sekolah, bahkan dikembangkan menjadi bagian dari kurikulum sekolah. Hal ini dapat diwujudkan apabila ada kerja sama antara Kementerian Pendidikan Nasional, Kementerian Kesehatan, serta pihak-pihak terkait lainnya.

Diharapkan juga remaja, khususnya siswa SMU di Surakarta terhindar dari ancaman yang sangat mencemaskan bagi keluarga khususnya dan suatu bangsa pada umumnya. Pengaruh NAPZA sangatlah buruk, baik dari segi kesehatan pribadi maupun dampak sosial yang ditimbulkan.

NAPZA dapat menimbulkan ketagihan dengan dampak merasa tidak nyaman dan kesakitan sehingga pengguna NAPZA selalu berusaha untuk mendapatkannya dengan melakukan apa saja misalnya mencuri, menodong bahkan membunuh. Pengguna NAPZA dapat kehilangan kontrol sehingga bisa melakukan hubungan seksual tidak aman, timbul kehamilan tidak diinginkan serta terjangkit penyakit menular. Pengguna NAPZA dengan jarum suntik bergantian dapat menularkan virus HIV serta hepatitis sehingga bisa berdampak kematian.

Masalah pencegahan penyalahgunaan NAPZA bukanlah menjadi tugas dari sekelompok orang saja, melainkan menjadi tugas kita bersama. Upaya pencegahan penyalahgunaan NAPZA yang dilakukan sejak dini sangatlah baik, tentunya dengan pengetahuan yang cukup tentang penanggulangan tersebut. Peran orang tua dalam keluarga dan juga peran pendidik di sekolah sangatlah besar untuk pencegahan dan penaggulangan NAPZA.

\section{KESIMPULAN DAN SARAN}

Terdapat hubungan antara Pembelajaran Kesehatan Reproduksi Remaja dengan pengetahuan NAPZA di SMU Surakarta, dimana pada kelompok siswa SMU di Surakarta yang telah diberikan pembelajaran kesehatan reproduksi remaja, jumlah siswa yang mengetahui tentang NAPZA lebih banyak dibandingkan yang belum mendapatkan pembelajaran, yang secara statistik bermakna.

Pada remaja khususnya siswa SMU di Surakarta yang belum diberikan pembelajaran, diberlakukan juga kebijakan pembelajaran kesehatan reproduksi remaja, sehingga pengetahuan remaja siswa SMU akan kesehatan reproduksi, khususnya NAPZA meningkat.

\section{DAFTAR PUSTAKA}

1. Martadisoebrata D, Sastrawinata S, Saifuddin AB. Bunga Rampai Obstetri dan Ginekologi Sosial. Jakarta: Yayasan Bina Pustaka Sarwono Prawirohardjo, 2005.

2. Badan Narkotika Nasional. Pedoman Pelaksanaan P4GN Melalui Peran Serta Kepala Desa/Lurah Babinkamtibmas dan PLKB di Tingkat Desa/Kelurahan. 2007

3. United Nations Office on Drugs and Crime. Drug trafficking. [internet] 2011[cited: 24 Juli 2014] Available from: http://www.unodc.org/ unodc/en/drug-trafficking/index.html

4. Universitas Sumatera Utara. Hubungan Faktor Internal dan Faktor Eksternal dengan Kekambuhan Kembali Pasien Penyalahguna NAPZA di Kabupaten Deli Serdang tahun 2012. Sumatera Utara, 2012.

5. Darmawan, B. Gejala Dini Penyalahgunaan Obat. Surabaya: Gramedia, 2000.

6. Kusmiran E. Kesehatan Reproduksi Remaja dan Wanita. Jakarta: Salemba Medika, 2011.

7. Mangku, M P, Mudji W, Arief S, Ulani Y. Pencegahan Narkoba Sejak Usia Dini. Jakarta: 
Badan Narkotika Nasional Republik Indonesia, 2007.

8. Sofyan, A. Narkoba Mengincar Anak Anda Panduan bagi Orang tua, Guru, dan Badan Narkotika. Penanggulangan Bahaya Narkoba di Kalangan Remaja. Jakarta: Prestasi Pustaka Publisher, 2007.

9. Sudarman, M. Sosiologi Untuk Kesehatan. Jakarta: Salemba Medika, 2008.

10. Putri EH. Gambaran Pengetahuan dan Upaya Pencegahan Terhadap Penyalahgunaan
Narkoba pada Remaja di SMK Negeri 2 Sragen Kabupaten Sragen. Sragen, 2012.

11. Faturachman M B. Peran Guru Pembimbing Dalam Upaya Pencegahan Penyalahgunaan Narkotika pada SMA Negeri dan Swasta Kota Palangkaraya. Kalimantan, 2006.

12. Widodo. Perilaku dalam Upaya Pencegahan Penyelahgunaan Narkoba pada Remaja Desa Gonilan Sukoharjo. Jawa Tengah. 2009 